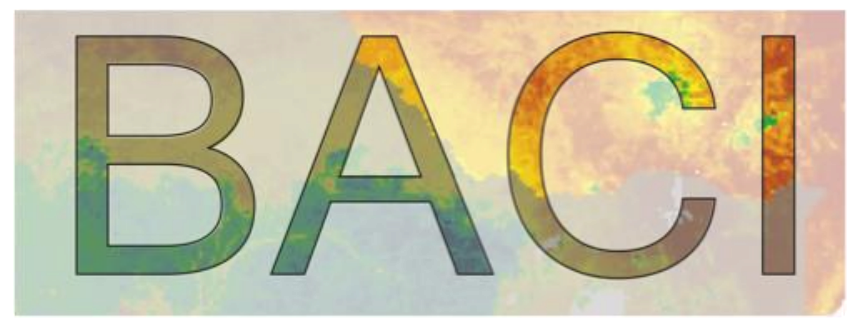

\title{
Land surface greening suggests vigorous woody regrowth throughout European semi-natural vegetation
}

\section{Postprint version}

Buitenwerf, R., Sandel, B., Normand, S., Mimet, A., \& Svenning, J.-C.

\section{Published in: Global Change Biology}

This is the peer reviewed version of the following article:

Reference: Buitenwerf, R., Sandel, B., Normand, S., Mimet, A., \& Svenning, J.-C. (2018). Land-surface greening suggests vigorous woody regrowth throughout European semi-natural vegetation. Global Change Biology, 24(12), 5789-5801. doi:10.1111/gcb. 14451

which has been published in final form at:

Web link: https://onlinelibrary.wiley.com/doi/full/10.1111/gcb.14451

This article may be used for non-commercial purposes in accordance with Wiley Terms and Conditions for Use of Self-Archived Versions. 


\title{
Land surface greening suggests vigorous woody regrowth throughout European semi-natural vegetation
}

\author{
Robert Buitenwerf $^{1,2}$ (1) | Brody Sandel ${ }^{1,3}$ | Signe Normand ${ }^{1,2}$ | Anne Mimet ${ }^{1,4}$ | \\ Jens-Christian Svenning ${ }^{1,2}$
}

${ }^{1}$ Section for Ecoinformatics and Biodiversity, Department of Bioscience, Aarhus University, Aarhus C, Denmark

${ }^{2}$ Department of Bioscience, Center for Biodiversity Dynamics in a Changing World (BIOCHANGE), Aarhus University, Aarhus C, Denmark

${ }^{3}$ Department of Biology, Santa Clara University, Santa Clara, California

${ }^{4}$ Biodiversity Conservation Group, German Center for Integrative Biodiversity Research (iDiv) Halle-Jena-Leipzig, Leipzig, Germany

\section{Correspondence}

Robert Buitenwerf, Section for

Ecoinformatics and Biodiversity, Department of Bioscience, Aarhus University, Aarhus C, Denmark.

Email: buitenwerf@bios.au.dk

\section{Funding information}

European Union's Horizon 2020 Research and Innovation Programme, Grant/Award Number: 640176; Carlsberg Foundation, Grant/Award Number: CF16-0005; VILLUM FONDEN, Grant/Award Number: 16549

\begin{abstract}
The satellite record has revealed substantial land surface "greening" in the northern hemisphere over recent decades. Process-based Earth system models (ESMs) attribute enhanced vegetation productivity (greening) to $\mathrm{CO}_{2}$ fertilisation. However, the models poorly reproduce observed spatial patterns of greening, suggesting that they ignore crucial processes. Here, we explore whether fine-scale land cover dynamics, as modified by ecological and land-use processes, can explain the discrepancy between models and satellite-based estimates of greening. We used $500 \mathrm{~m}$ satellitederived Leaf Area Index (LAI) to quantify greening. We focus on semi-natural vegetation in Europe, and distinguish between conservation areas and unprotected land. Within these ecological and land-use categories, we then explored the relationships between vegetation change and major climatic gradients. Despite the relatively short time-series (15 years), we found a strong overall increase in LAI (i.e., greening) across all European semi-natural vegetation types. The spatial pattern of vegetation change identifies land-use change, particularly land abandonment, as a major initiator of vegetation change both in- and outside of protected areas. The strongest LAI increases were observed in mild climates, consistent with more vigorous woody regrowth after cessation of intensive management in these environments. Surprisingly, rates of vegetation change within protected areas did not differ significantly from unprotected semi-natural vegetation. Overall, the detected LAI increases are consistent with previous, coarser-scale, studies. The evidence indicates that woody regrowth following land abandonment is an important driver of land surface greening throughout Europe. The results offer an explanation for the large discrepancies between ESM-derived and satellite-derived greening estimates and thus generate new avenues for improving the ESMs on which we rely for crucial climate forecasts.

KEYWORDS

LAI, land abandonment, land surface greening, Leaf Area Index, remote sensing, vegetation change, woody expansion
\end{abstract}

\section{1 | INTRODUCTION}

Humans have driven the Earth's atmosphere, geosphere and biosphere well beyond conditions typical of the current interglacial. A key manifestation of the Anthropocene is global-scale land surface modifications (Steffen, Broadgate, Deutsch, Gaffney, \& Ludwig, 2015), especially vegetation change, which strongly controls the global energy balance and the fluxes of major elements including carbon, nitrogen and water. Vegetation can therefore accelerate or 
decelerate further climatic or atmospheric change. Vegetation is also controlled by atmospheric and climatic change, resulting in various feedback loops between vegetation and the atmosphere (Bonan, 2016).

These feedback loops are partly regulated by biological processes that act on very different time scales. At the fast end, photosynthetic rates and stomatal aperture can be adjusted within seconds. On longer time scales, individual plants may adjust anatomically to prevailing environmental conditions, for example, increasing stomatal density in response to elevated atmospheric $\mathrm{CO}_{2}$ (Woodward, 1987). Even slower, range shifts in slow-reproducing or slow-dispersing trees may take millennia (Svenning \& Skov, 2004), while evolutionary adaptations to environmental conditions can play out over millions of years (Osborne \& Beerling, 2006). Observed vegetation change is thus a complex end result of many interacting processes that operate at different spatial and temporal scales.

One particularly conspicuous and relevant example of such complex vegetation change is land surface "greening." Greening refers to increases in several variables that are associated with vegetation productivity, "activity" or density. These variables include Normalised Difference Vegetation Index (NDVI), Leaf Area Index (LAI) and net primary production (NPP) and are derived from satellitebased observation since the early 1980s. The satellite data show that greening is a global phenomenon, although particularly prevalent in the northern hemisphere (Buitenwerf, Rose, \& Higgins, 2015; De Jong, Verbesselt, Schaepman, \& Bruin, 2012; Garonna et al., 2014; Mao et al., 2016; Nemani et al., 2003; Zhu et al., 2016).

Identifying the drivers of observed greening is a complex task, but recent studies have made advances using Earth system models (ESMs) (Anav et al., 2013; Mao et al., 2016; Murray-Tortarolo et al., 2013; Zhu et al., 2016). ESMs are process-based models used in climate forecasts. In the land surface components of these models LAl, the one-sided leaf area $\left(\mathrm{m}^{2}\right)$ per ground area $\left(\mathrm{m}^{2}\right)$ is a key variable. Simulation experiments can therefore be used to predict LAI under various climate and atmospheric change scenarios. By comparing modelled LAI with satellite observations, it is possible to identify the most important forcing variables (e.g., atmospheric $\mathrm{CO}_{2}$ or temperature) that drive LAI increases. In these comparisons, satellite-derived greening rates are assumed to be representative of actual greening.

Current models reproduce the global average of satellite-based greening rates fairly accurately. However, the models performed poorly at simulating the spatial pattern of satellite-based greening estimates (Mao et al., 2016). For example, ESMs tended to overestimate greening in western North America, while severely underestimating greening in Europe. This may indicate that important processes are either not well represented or not well parametrised in ESMs. A misrepresentation of processes suggests that sufficient mechanistic understanding of the system is lacking, while misparametrisation, although less severe, introduces error into model projections. This is problematic, as ESMs are the primary tool for climate forecasts.

Leaf Area Index predictions in ESMs can likely be improved by including more and better-parametrised plant functional types (now typically 4-16) and by better representing seasonal leaf phenology (Anav et al., 2013). However, the spatial discrepancies between modelled and satellite-derived LAI suggest an additional issue. Both individual species and vegetation types (e.g., biomes) may not be present in all locations with suitable environmental conditions. This situation, often referred to as disequilibrium, can be caused by ecological processes such as dispersal limitation (Svenning \& Skov, 2004), competitive exclusion (Svenning \& Sandel, 2013) or by disturbance such as fire (Bond, Woodward, \& Midgley, 2005).

In this study, we hypothesise that disequilibrium resulting from land-use and ecological succession may explain the mismatches between modelled and observed greening rates in Europe. Specifically, we expect that succession towards more woody vegetation states, that is, forest regrowth, in semi-natural vegetation is an important driver of observed greening over the past decades.

Succession towards closed-canopy forest is the norm for environments that can support tall trees and in which disturbance, for example, by humans, fire or mammalian herbivores, is not frequent or severe enough to keep the vegetation open (Bond et al., 2005). However, if succession does indeed contribute to observe greening, it also raises the question of which processes have initiated or expedited succession. To assess whether land-use change in the form of intensified conservation efforts during the past decades has affected greening in semi-natural vegetation, we contrast areas managed for biodiversity conservation with areas managed for other objectives.

Finally, we address a common assumption in large-scale analyses of satellite data, which is that greening follows a linear trajectory (De Jong et al., 2012). When analysing time-series for many millions of pixels, it is unfeasible to assess each pixel individually and select an appropriate model. Moreover, such an approach would obstruct a comparison of rates of change between pixels. However, practical considerations aside, there is no a priori reason to expect that LAI change should be linear. In fact, many ecological processes relevant to vegetation change are known to be highly non-linear, including population growth, seed dispersal kernels and the transition from one vegetation state to another. Indeed, empirical and theoretical work shows that transitions from disturbance-maintained partly open vegetation to closed-canopy forest can happen very rapidly (Aleman \& Staver, 2018; Smit, Ruifrok, Klink, \& Olff, 2015). To assess the impact of assuming linear change in LAl time-series studies, we estimate the degree of non-linearity using a time-series segmentation approach.

In summary, the main study aim was to determine whether finescale land cover can explain mismatches between satellite and model-based estimates of land surface greening. Specifically, can land abandonment in Europe, followed by ecological succession, account for observed greening that outpace model-based estimates? We furthermore ask whether other forms of land-use (protected vs. unprotected areas) affect greening rates. Finally, we ask whether the widespread statistical assumption of linear change in land surface studies based on satellite data is likely to affect reported estimates of change. 


\section{2 | MATERIALS AND METHODS}

\subsection{Data}

\subsection{1 | Leaf Area Index}

LAl for broadleaved vegetation can be interpreted as the one-sided leaf area $\left(\mathrm{m}^{2}\right)$ per ground area $\left(\mathrm{m}^{2}\right)$ and as half the total leaf area per ground area for needle-leaved vegetation (Myneni, Knyazikhin, \& Park, 2015). LAl therefore contains information on both the structure of vegetation (e.g., broadleaved vs. conifer forest) and productivity (e.g., dense vs. sparse canopies). To quantify vegetation dynamics, we used LAI derived from the MODIS sensor on NASA's Terra satellite. The LAl product is provided as 8-day composite images at 500-m resolution (Myneni et al., 2015, downloaded 6 May 2016). Product quality control layers were used to discard pixels with poor-quality data and only retain pixels with confidence classes "best result possible" and "good, very usable."

\subsection{2 | Natura 2000}

Natura 2000 is the primary network of protected areas within the European Union. In 2015, it consisted of 23,115 terrestrial reserves that together cover approximately $18 \%\left(794,368 \mathrm{~km}^{2}\right)$ of the EU land surface. Within the network, large differences between sites exist in terms of reserve size, connectivity, protection status before the inception of Natura 2000 in 1992, implementation of management strategies, etc. The boundaries of Natura 2000 protected areas for 2015 were extracted from a digital map by the European Environment Agency (2016b).

\subsection{3 | Land cover}

In order to delineate areas that are not intensively used by humans, we used the 2006 version of the CORINE land cover product to select nine classes of "natural" and "semi-natural" land cover types. These land cover types will henceforth be referred to as semi-natural vegetation, recognizing that nearly all such areas have been influenced by human activities to some degree. Land cover types and details of area are given in Table 1. The CORINE land cover map was downloaded as a grid with a cell size of $100 \times 100 \mathrm{~m}$ (European Environment Agency, 2016a). We ensured that the 2006 land cover map was representative of the entire 2001-2015 study period by performing a sensitivity analysis using earlier (2000) and later (2012) versions of CORINE land cover. Estimates of temporal LAI change produced using the 2000 and 2012 land cover maps were qualitatively and quantitatively similar to results using 2006 land cover.

\subsection{4 | Environmental data}

To quantify LAl change along environmental gradients, we used monthly mean temperatures (Hijmans et al. 2005) and monthly mean soil moisture balance calculated from estimates of actual
TABLE 1 Proportion of the study area occupied by selected seminatural CORINE land cover classes (vegetation types)

\begin{tabular}{|lll|}
\hline Vegetation type & $\begin{array}{l}\text { Area (\% of } \\
\text { study area) }\end{array}$ & $\begin{array}{l}\text { Area inside N2000 (\% of } \\
\text { previous column) }\end{array}$ \\
\hline Broadleaved forest & 19.5 & 39.1 \\
\hline Coniferous forest & 35.3 & 18.2 \\
\hline Mixed forest & 14.5 & 21.4 \\
\hline $\begin{array}{l}\text { Transitional } \\
\text { woodland-shrub }\end{array}$ & 11.1 & 20.3 \\
\hline $\begin{array}{l}\text { Sclerophyllous } \\
\text { vegetation }\end{array}$ & 4.0 & 39.9 \\
\hline $\begin{array}{l}\text { Natural grasslands } \\
\text { Inland marshes }\end{array}$ & 5.6 & 41.3 \\
\hline Peat bogs & 0.3 & 81.6 \\
\hline Moors and & 4.9 & 34.1 \\
\hline heathlands & 4.8 & 44.7 \\
\hline
\end{tabular}

Note. The third column shows area within the Natura 2000 network. The total study area is $1,402,123 \mathrm{~km}^{2}$ and is further described in text and Figure 1.

evapotranspiration, precipitation and run-off (Trabucco \& Zomer, 2010). Both temperature and moisture impose fundamental constraints on plant functioning. These variables are not independent (Pearson's $\rho=0.66$ ) as soil moisture is partly regulated by evapotranspiration, which in turn is partly regulated by temperature. However, since temperature not only affects plant functioning through water relations, but also directly affects physiological (e.g., photosynthetic rate) and behavioural (e.g., leaf expansion) processes, there is a need to interpret both variables separately and interactively. Data for all variables are long-term averages over 1960-1990 and were extracted from global grids with a resolution of $30 \operatorname{arcsec}( \pm 1 \mathrm{~km})$.

\subsection{Data harmonisation}

For every $500 \mathrm{~m}$ LAl grid cell, we determined the cover of selected semi-natural vegetation types and discarded cells with $<80 \%$ seminatural vegetation cover. Each remaining cell was then assigned to a semi-natural land cover type, based on the dominant type within the cell. The $80 \%$ cut-off ensures a focus on areas dominated by seminatural vegetation, while still allowing the inclusion of mosaic landscapes, where the cover of semi-natural vegetation might be $<100 \%$ in most pixels. A sensitivity analysis using higher (92\%) and lower (68\%) cut-offs showed that the $80 \%$ cut-off did not qualitatively affect estimates of temporal LAl change and that quantitative differences were minimal.

Within this subset of cells, we determined the area under Natura 2000 protection and excluded cells with $<80 \%$ Natura 2000 cover from the change analysis, that is, we compared cells without Natura 2000 protection to cells with $>80 \%$ Natura 2000 protection. Environmental data (temperature and soil moisture) were re-projected and resampled to the $500 \mathrm{~m}$ LAl grid. These operations yielded a data set with 1,534,477 Natura 2000 pixels and 4,074,014 pixels 
outside Natura 2000. Most protected areas were small, with a median of 11 selected pixels per Natura 2000 area (approximately $2.75 \mathrm{~km}^{2}$ ). All spatial operations were performed using the raster package (Hijmans, 2018) in R (R Core Team, 2018).

\section{3 | Change analysis}

\subsection{1 | Temporal LAl change}

We quantified the magnitude of LAl change for all selected pixels using annual means from 2001 to 2015. Previous studies have typically averaged LAI over the most productive part of the year, thus focussing on growing season productivity. Here, we chose to be more inclusive and use LAI data over the entire year. This allowed us to quantifying greening that results from temporal shifts in the annual growing cycle, for example, because of earlier warming-induced leaf emergence in spring (Menzel et al., 2006) or prolonged autumn growth as a result of changing community composition (Fridley, 2012). Moreover, aggregating reflectance-based time-series to annual values results in more reliable estimates of change (Forkel et al., 2013). We quantified changes in annual LAI means using the Theil-Sen estimator, which is a robust non-parametric estimator of linear slope. Preliminary testing showed that for these data, TheilSen slopes were near-identical to an alternative robust measure of change as described in (Buitenwerf et al., 2015). Theil-Sen analyses were implemented using the rkt package (Marchetto, 2015) for $R(R$ Core Team, 2018).

\subsection{2 | LAl change in protected versus unprotected land}

In comparing LAI change between areas in and outside of the Natura 2000 network, it must be recognised that environmental conditions within the study area vary substantially. Similarly, the biogeographic template (e.g., regional species pools, glaciation history) varies considerably across Europe. To account for this variation, we only compared pixels with similar climates, within the same vegetation type (similar ecological processes) and within a $50 \mathrm{~km}$ radius (similar biogeographic setting). Environmental similarity between pixels was defined as the minimum Euclidean distance in multidimensional environmental space, which consisted of scaled monthly mean temperatures and monthly mean soil moisture.

\subsubsection{Non-linearity of LAl change trajectory}

To gain further insight into the (potentially non-linear) shape of LAI time-series, we employed a time-series trend-break analysis. This algorithm identifies how many contiguous linear segments best describe a time-series. A slope and intercept are estimated for each linear segment.

The algorithm was applied to the full 8-day interval LAI time-series from 2001 to 2015. First, each time-series is decomposed into seasonal, multi-year trend and noise components. For the trend- break analysis, we focussed on the multi-year trend component, for which we set a minimum segment length of 3 years, yielding a maximum of five linear segments in the 15-year time-series. Due to computational limitations, the trend-break analysis was performed on a random subset (50\%) of pixels selected in the steps described previously. Trend-break analyses were implemented using the bfast package (Verbesselt, Hyndman, Newnham, \& Culvenor, 2010) for R (R Core Team, 2018).

\section{3 | RESULTS}

\section{1 | Magnitude of LAl change}

Leaf Area Index increased in $84 \%$ of pixels with semi-natural vegetation across Europe (Figure 1 and Supporting Information Figure S1). The largest increases were detected in Eastern Europe, particularly in Poland, the Czech Republic, Slovakia and Romania. The most notable decreases were detected in the Landes forest of south-western France, the Ardennes region of Belgium, the British Isles and in parts of northern Scandinavia. More moderate decreases were detected in the southern Alps and south-western Sweden.

Absolute LAI increases were greatest in high-biomass vegetation types (i.e., forest). In low-biomass vegetation, absolute increases were less pronounced but still positive for the majority of pixels (Figure 2a). However, when change was expressed in relative terms, that is, as a proportion of long-term mean annual LAl within each pixel, increases were the largest in vegetation types of intermediate biomass and woody cover (Figure $2 b$ ).

Without taking account of climatic, ecological and biogeographical differences between pixels, Figure 2 shows that the magnitude of LAI increase was similar in protected and unprotected areas. There were minor differences, for example, LAl in forests and grassland tended to increase more inside than outside Natura 2000, while LAI in partly wooded vegetation types (transitional woodland-shrub and sclerophyllous vegetation) increased slightly more outside Natura 2000. However, the variance of LAl increase within each vegetation type was large (Figure 2), potentially reflecting climatic and biogeographic differences between pixels of the same vegetation type. Surprisingly, comparing only climatically, ecologically and biogeographically analogous pixels did not expose differences between pixels with contrasting protection status. Differences between analogous pixels in- and outside N2000 were unimodally distributed around zero for all vegetation types (Supporting Information Figure S1).

Although taking account of the climate did not expose expected differences between protected and unprotected areas, climatic conditions strongly modulated observed LAl dynamics. Notably, the smallest LAI increases occurred in the coldest areas within all vegetation types (Figure 3), consistent with a temperature constraint on productivity and woody cover. In most vegetation types, LAI increases were greater in areas with intermediate temperatures than in the warmest areas, yielding a hump-shaped relationship between $\Delta \mathrm{LAl}$ and mean annual temperature. A similar relationship emerged 


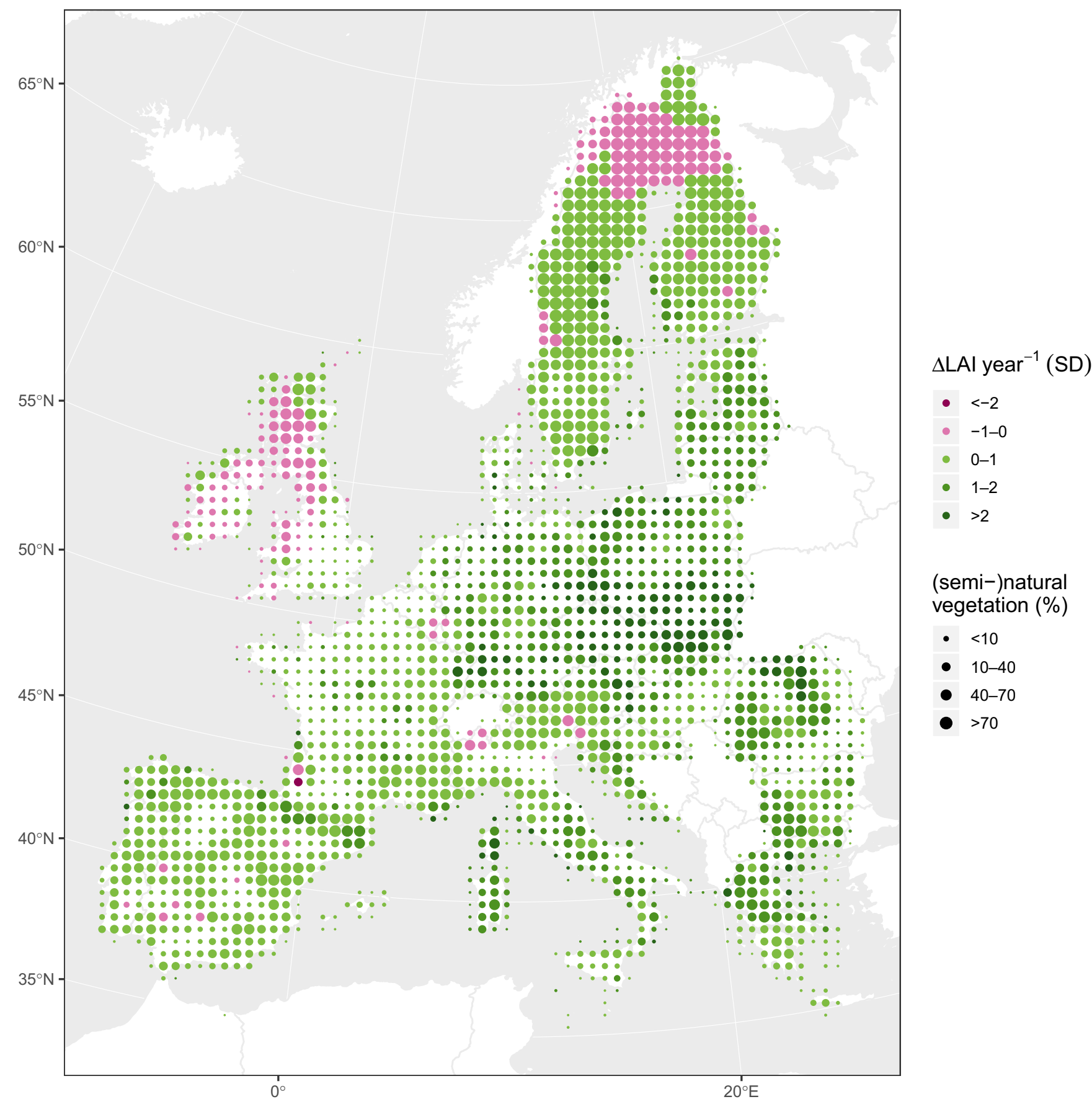

FIGURE 1 Temporal change in the structure of semi-natural vegetation of Europe. Change was quantified using the Theil-Sen estimator of annual Leaf Area Index (LAI) means from 2001 to 2015. Colour breaks are placed at multiples of the $\Delta$ LAl standard deviation. The map is projected in an equal area projection (EPSG:3035) [Colour figure can be viewed at wileyonlinelibrary.com]

between $\Delta \mathrm{LAl}$ and soil moisture, with the largest LAl increases in areas with intermediate soil moisture and smaller LAI increases in dry and very wet areas (Figure 4).

\section{2 | Non-linearity of LAl change trajectory}

$26.5 \%$ of pixels changed monotonically (Mann-Kendall $p<0.05$ ), and the patterns shown in Figures 1-4 were very similar when only considering pixels with monotonic LAl change.
Figure 5 shows that for the majority of pixels (60\%), a standard linear regression without any abrupt break points was the best model to describe $\Delta$ LAl. Approximately $20 \%$ of pixels were best described by two linear segments, $13 \%$ by three linear segments and a small minority by more than three linear segments. This pattern was consistent across vegetation types.

However, vegetation type affected the relationship between the magnitude of temporal LAl change and the non-linearity of the timeseries giving rise to that change. For example, in broadleaved forest, 
(a)

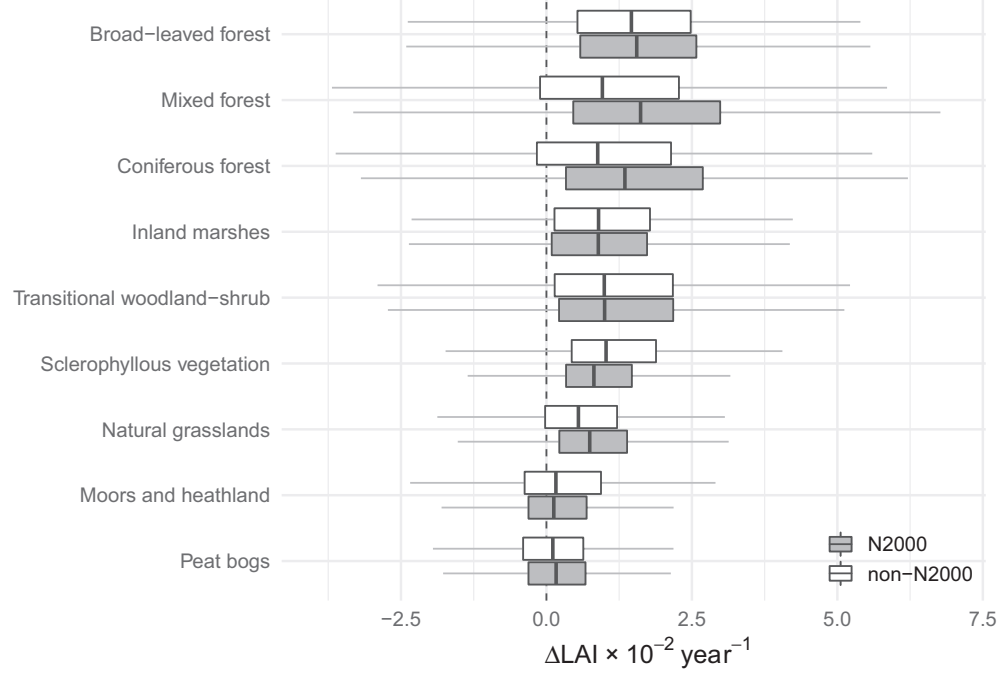

(b)

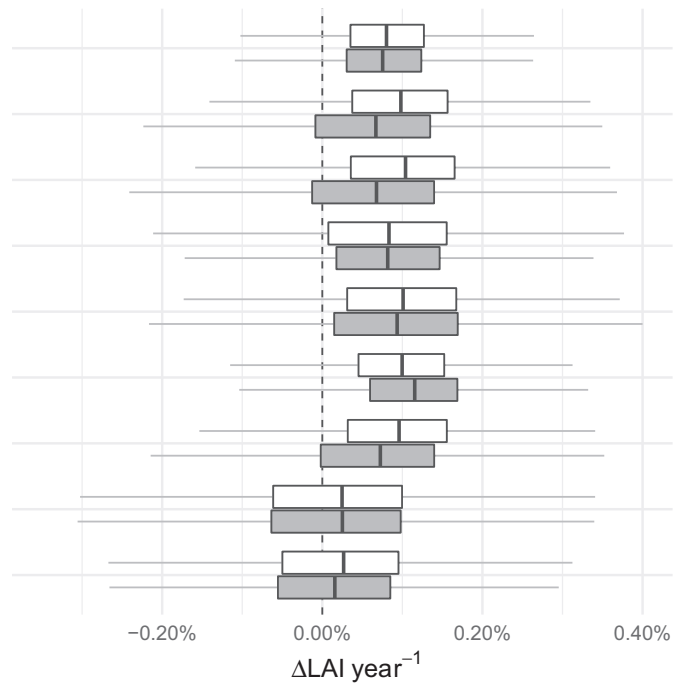

FIGURE 2 Annual Leaf Area Index (LAI) change in semi-natural vegetation types of Europe in absolute units (a) and relative to the longterm mean LAI (b). Vegetation types are arranged from low mean annual LAI (bottom) to high mean annual LAI (top). Vegetation change was quantified using the Theil-Sen estimator of annual LAI means from 2001 to 2015 . Vegetation types were taken from the 2006 CORINE land cover map. Within each vegetation type, change is shown for pixels inside and outside the Natura 2000 network of protected areas

the largest LAI increases emerged from the most complex LAI timeseries, that is, time-series best captured by four or five linear segments. In contrast, conifer and mixed forests showed the opposite pattern, with the largest LAI increases emerging from linear time-series (a single segment). Since two to five linear segments could describe a multitude of possible change trajectories, it is complicated to summarise and interpret these results further. Nonetheless, the results suggest that linear models may not be appropriate to quantify LAl change in the most rapidly changing areas in at least five out of the nine main semi-natural vegetation types in Europe.

Finally, within vegetation types, the relationship between timeseries complexity and the rate of LAI increase tended to be similar for protected and unprotected pixels. The largest exception was transitional woodland scrub, where in protected pixels, the greatest LAI increase emerged from linear (one segment) time-series, while in unprotected pixels, the greatest LAl increase emerged from the most complex time-series (five segments).

\section{DISCUSSION}

In this study, we assessed whether land-use, land-use change and ecological processes contribute to land surface greening in European semi-natural vegetation. These processes may explain important mismatches between satellite-derived ("observed") and modelled greening rates. We found widespread LAI increases (i.e., greening) throughout Europe's semi-natural vegetation. Greening rates in conservation areas did not exceed greening in unprotected semi-natural vegetation, suggesting that increased conservation efforts have not contributed to greening. However, the spatial signature of LAI increase strongly suggests that land-use change in the form of land abandonment allows succession (forest regrowth) to proceed. Finally, we show that although the degree of non-linearity in LAl time-series is substantial, linear models appropriately capture inter-annual LAI dynamics on most of the land surface.

\section{1 | LAl increases}

Despite the relatively short time-series (2001-2015), we detected greening in $84 \%$ of pixels with semi-natural vegetation. This result is consistent with previous studies that detected greening from satellite data, although not directly comparable. Previous studies have used coarser-scale land cover and greenness data (De Jong et al., 2012), inevitably mixing semi-natural vegetation with intensively farmed land, where inter-annual LAI tends to be highly variable due to, for example, crop rotation cycles. The higher-resolution LAI data used here in combination with a high-resolution land cover map allowed us to focus on land with semi-natural vegetation and describe the greening signal for individual vegetation types.

Relative increases (i.e., $\Delta \mathrm{LAl}$ expressed in percentages) were highest in "transitional woodland-shrub" and "sclerophyllous vegetation," consistent with increasing woody cover in these semi-open vegetation types (Timmermann, Damgaard, Strandberg, \& Svenning, 2015). The large absolute increases in forests may not represent increases in woody cover, but rather forest growth, where increasingly tall trees support a denser canopy and thus increase LAI (Pretzsch, Biber, Schutze, Uhl, \& Rotzer, 2014). However, since we quantified LAl as the integral throughout the entire year, it is likely that part of the observed greening is due to increasingly long green seasons (Buitenwerf et al., 2015). Longer green seasons in Europe result from longer growing seasons due to spring warming (Menzel et al., 2006), but at local scales, other processes may contribute, including the spread of evergreens (Hernández, Dios, Montes, Sainz- 

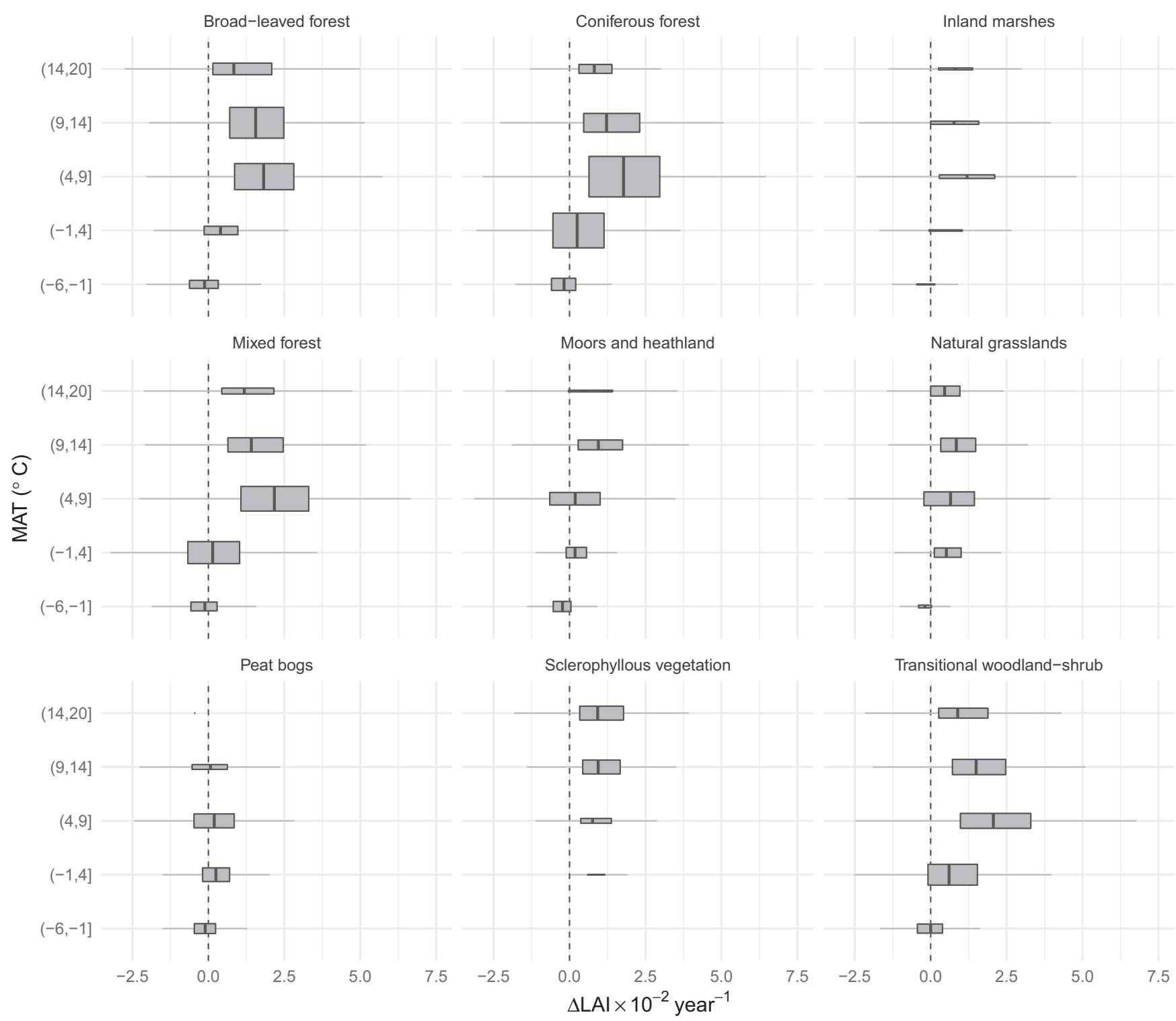

FIGURE 3 Vegetation change in semi-natural vegetation varies with mean annual temperature (MAT). Vegetation change was quantified using the Theil-Sen estimator of annual Leaf Area Index (LAI) means from 2001 to 2015 . MAT is collapsed into $3^{\circ} \mathrm{C}$ bins and the width of the boxes represents the number of pixels per bin. The vertical dashed line indicates zero LAI change. Boxes contain data points between the first and third quartile (IQR) and the vertical bars show the median. The whiskers contain data points within $1.5 \times$ IQR

Ollero, \& Canellas, 2017; Thiele, Kollmann, \& Andersen, 2009; Walther et al., 2007) and immigration by species that can take advantage of warmer autumn temperatures (Fridley, 2012).

We also explored relationships between $\Delta \mathrm{LAl}$ and temperature and moisture, which are the primary climatic drivers of vegetation dynamics in this area (Ciais, Reichstein, \& Viovy, 2005; Jung et al., 2017). $\triangle$ LAl peaked at intermediate to high MAT and MAM, that is, in climatically mild areas (Figures 3 and 4).

If temperature and moisture indeed cause LAI to increase, there are two broad possible explanations. First, climatically mild areas may simply allow LAl to increase faster compared to areas with more extreme climates. Mild climates could simply allow biochemical and physiological growth processes to proceed at faster rates, but more indirect effects can also be important. For example, mild climates support intrinsically faster-growing species (Reich, Walters, \& Ellsworth, 1997), and climate warming may extend the effective growing season length (i.e., the number of growing hours or days) more in mild than in harsher climates (Garonna et al., 2014). Second, areas with mild climates may have a higher potential LAI. Physiological processes set limits on the potential natural vegetation (i.e., when vegetation is at equilibrium with the environment) for a given set of environmental conditions (Hickler et al., 2012). For example, cold temperatures restrict ranges of European trees (Körner et al., 2016), while drought limits tree establishment and causes canopy dieback in southern Europe (Castro, Zamora, Hódar, \& Gómez, 2005; Lloret, Siscart, \& Dalmases, 2004). Alternatively, LAl at the start of the observation period may be further from the potential LAl because it has been suppressed by humans, for 


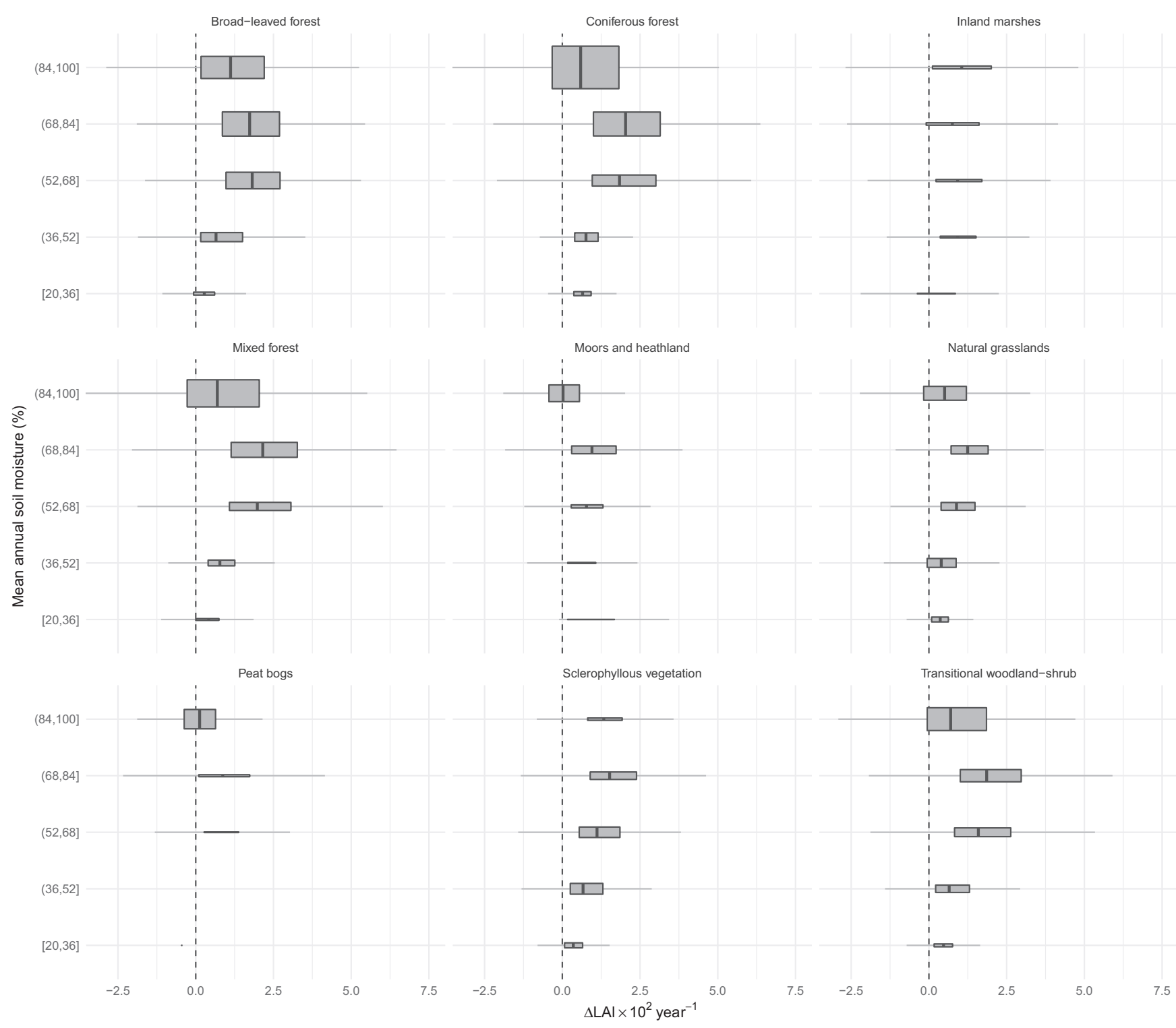

FIGURE 4 Vegetation change in semi-natural vegetation varies with mean annual soil moisture (MAM). Vegetation change was quantified using the Theil-Sen estimator of annual Leaf Area Index (LAI) means from 2001 to 2015 . MAM is collapsed into $16 \%$ bins and the width of the boxes represents the number of pixels per bin. The vertical dashed line indicates zero LAl change. Boxes contain data points between the first and third quartile (IQR), and the vertical bars show the median. The whiskers contain data points within $1.5 \times$ IQR

example, because climatically mild areas are also the most suitable for agriculture. A release from agriculture through land abandonment could then result in rapid LAI increases towards the potential maximum.

While testing the purely ecological mechanisms suggested above would require additional data, there is good evidence to support release from agriculture (land abandonment) as a driving process. The spatial signature of LAl increase strongly corresponds to areas where land abandonment is widespread, such as in Eastern Europe and mountainous regions of southern and central Europe (Figure 1 and Supporting Information Figure S1). Land-use dynamics are a complex interplay of spatial and temporal processes, but a few key socioeconomic and political developments can account for an important part of the spatial signature in LAl change (MacDonald et al.,
2000; Navarro \& Pereira, 2012; Plieninger et al., 2016). The dissolution of the Soviet Union in 1991 ended large-scale governmentplanned and subsidised agriculture across Eastern Europe, resulting in widespread abandonment of cropland (Estel et al., 2015; Kuemmerle et al., 2016; MacDonald et al., 2000; Skaloš et al., 2015). Simultaneously, the early 1990s saw reforms to the EU's Common Agricultural Policy, which was designed to implement agricultural subsidies. Measures to counter overproduction and adapt to increasingly free markets forced less profitable areas out of cultivation, particularly affecting regions of Portugal, Spain and Italy (Fuchs, Herold, Verburg, Clevers, \& Eberle, 2015; Regos et al., 2016). Upon abandonment, succession towards increasingly woody plant communities is no longer inhibited (Gellrich, Baur, Koch, \& Zimmermann, 2007; Timmermann et al., 2015). 

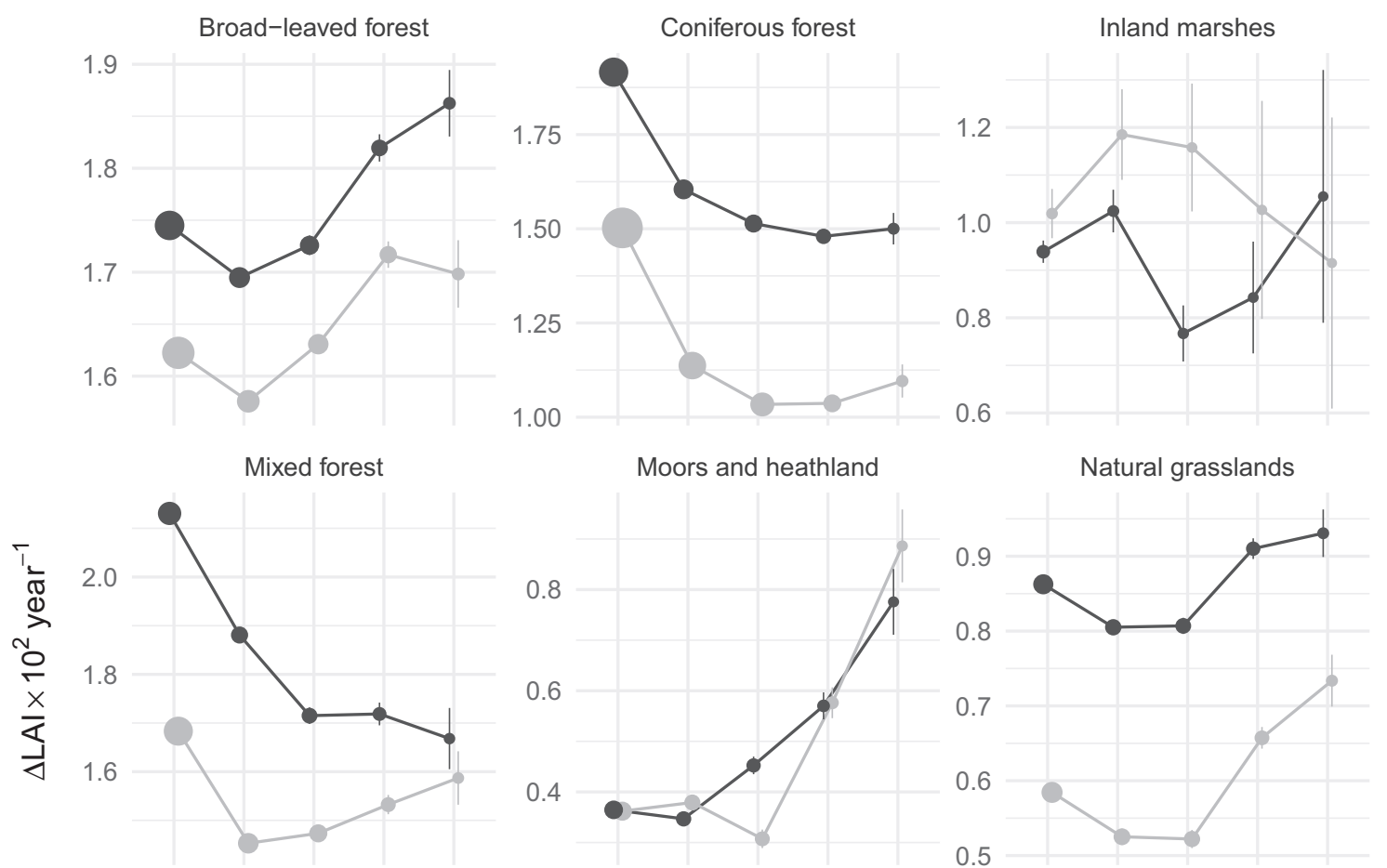

(semi-)natural area (\%)
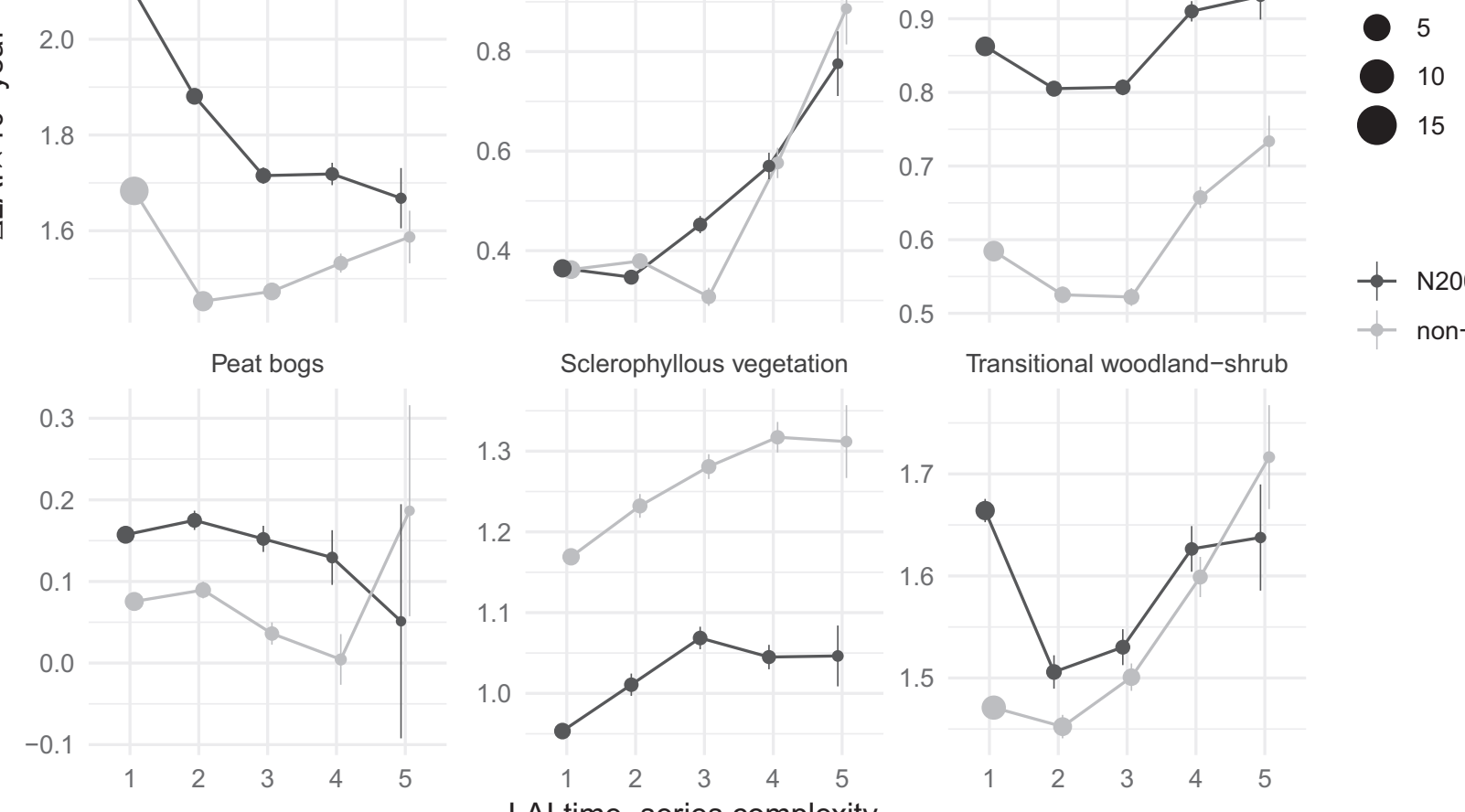

LAl time-series complexity (\# of linear segments)

FIGURE 5 The relationship between temporal Leaf Area Index (LAl) change and time-series complexity. Time-series complexity is represented by the number of linear segments required to describe a LAl time-series. A single segment is a standard linear regression, while two linear segments indicate one abrupt break point in the LAI time-series. Data represent LAI change in semi-natural European vegetation in and outside of the Natura 2000 network. The dots show mean LAl change, error bars show the standard error of the mean. The size of the dots is proportional to the number of pixels it represents

In summary, these results suggest that ESMs may be improved by representing turnover in the composition and structure of plant communities that are initiated by changes in land-use and driven by ecological processes. Furthermore, the discrepancy between observed and modelled LAI may be even larger than recent studies suggest, since physiological processes that translate atmospheric $\mathrm{CO}_{2}$ into primary productivity (i.e., plant growth) are not well represented in ESMs (Fatichi, Leuzinger, \& Körner, 2014). Small-scale $\mathrm{CO}_{2}$ enrichment experiments suggest that at least some European forest trees are not carbon limited at ambient $\mathrm{CO}_{2}$ (Bader et al., 2013), although this does not exclude the possibility of carbon limitation at pre-industrial $\mathrm{CO}_{2}$.

\subsection{LAl decreases}

Although LAI increased in most semi-natural vegetation, several regions had predominantly negative $\Delta$ LAl. One such "browning" hotspot was the Landes forest in south-western France (Figure 1), where the 2009 storm Klaus caused major windthrow in the planted maritime pine (Pinus pinaster) forests that dominate this region (Mora, Banos, Regolini, \& Carnus, 2014). LAl decreases in the United Kingdom cannot be easily explained by such an episodic disturbance since the majority of semi-natural vegetation consists of moors, heaths and grassland. Compared to mainland Europe, the United Kingdom has large populations of deer (Gill \& Morgan, 2010; 
Putman, Langbein, Green, \& Watson, 2011) and sheep (European Commision, 2017), suggesting that intense grazing and browsing pressure in open vegetation types may be responsible for the anomalous LAI decreases in the United Kingdom. Herbivore suppression of woody plant growth (Churski, Bubnicki, Jedrzejewska, Kuijper, \& Cromsigt, 2017) may also be responsible for LAI declines in northern Scandinavia, where intense reindeer grazing has been shown to reduce shrub cover (Cohen et al., 2013; den Herder, Virtanen, \& Roininen, 2008). In addition, northern Scandinavia has been subjected to outbreaks of geometrid moths, which defoliate large areas of birch forest (Jepsen et al., 2009) and may be related to climate change (Hagen, Jepsen, Ims, \& Yoccoz, 2007; Young, Cairns, Lafon, \& Moen, 2014).

\section{3 | LAl change in protected versus unprotected land}

Counter to our expectations, the magnitude of LAl change in Natura 2000 protected areas did not differ consistently from unprotected areas (Figure 2). This suggests that management implemented under Natura 2000 directives did not significantly modify $\Delta$ LAl. Management goals and the level of implementation are known to vary widely among Natura 2000 sites, with some sites being managed primarily to protect rare bird or plant species and others more generally to maintain or increase biodiversity (Kremer, Stegen, Gomez-Zamalloa, \& Szedlak, 2015). This variability in the mode and intensity of human impact may prevent a uniform response signal in a complex variable such as LAI.

\subsection{Non-linearity of LAI change trajectory}

Although $\triangle \mathrm{LAl}$ did not differ between Natura 2000 and unprotected sites, there appeared to be some differentiation in the shapes of LAI change trajectories for certain vegetation types (Figure 5). The shape of the change trajectory refers to the number of linear segments needed to accurately describe the LAl time-series in a pixel. The shape of the change trajectory cannot easily be interpreted ecologically without more information on underlying processes. However, differences in the relationship between the magnitude of vegetation change ( $\Delta \mathrm{LAl}$ ) and the change trajectory (number of linear segments) between Natura 2000 and unprotected areas may indicate a management effect on vegetation dynamics that does not (yet) affect $\Delta$ LAl. An example of management intervention in Natura 2000 areas may be continuation of traditional farming practices. Such practices are typically extensive and labour intensive, and are in certain cases subsidised by the EU (Bignal \& McCracken, 2000; Lomba, Alves, Jongman, \& Mccracken, 2015; Olmeda, Keenleyside, Tucker, \& Underwood, 2014).

If differences in change trajectories signal management induced changes to ecosystem functioning, they may precede impending divergence in LAI magnitude and hence serve as early warning flags for future vegetation change (Verbesselt et al., 2016). Alternatively, or simultaneously, it is possible that management does not affect vegetation state but rather the resistance or resilience to (environmental or anthropogenic) perturbations.

\section{5 | Biodiversity implications}

Just like the major shifts in land-use following land abandonment affect biodiversity (Cramer, Hobbs, \& Standish, 2008; Guilherme \& Pereira, 2013; Queiroz, Beilin, Folke, \& Lindborg, 2014), the potentially subtle effects of Natura 2000 management on vegetation change trajectories are also likely to have consequences for biodiversity. Although direct links to, for example, the distribution and population dynamics of individual species are difficult to make without more detailed ground-based data, our findings generate some useful question and hypotheses for future studies. For example, partially wooded vegetation types had the largest proportional increases in LAI (Figure 2b). These increases were smaller in Natura 2000 areas than in unprotected areas, suggesting lower rates of woody expansion under Natura 2000 management. However, it has been argued that woody expansion may be favourable for overall biodiversity (Navarro \& Pereira, 2012). Forests, especially old-growth forests, are important reservoirs of biodiversity in Europe because they engineer structurally complex habitat and support a large number of species that are associated with dead wood (Lassauce, Paillet, Jactel, \& Bouget, 2011; Ódor et al., 2006). Furthermore, old-growth forests may be more resilient to climate fluctuations (Musavi et al., 2017).

Despite these benefits of old-growth forest, a large proportion of European biodiversity depends on open and semi-open habitats. Such species are threatened by uniform succession towards dense woody vegetation. For example, species of butterfly require both forest and open vegetation and are already declining due to loss of forest glades (Freese et al., 2006; Van Swaay, Warren, \& Loïs, 2006). The general woody regrowth is clearly linked to fundamental societal changes driving the abandonment of extensive traditional agricultural land-use, and it seems unrealistic to reinstall such practices across large areas. A more tractable solution may be to promote restoration of diverse assemblages of wild large herbivores, via facilitating spontaneous comebacks and via reintroduction, that is, trophic rewilding (Svenning et al., 2016), which in the past have been able to maintain substantial open and semi-open vegetation in European temperate landscapes (Sandom, Ejrnaes, Hansen, \& Svenning, 2014; Van Wieren, 1995).

In conclusion, land surface greening is both widespread and pronounced in Europe's semi-natural vegetation. The spatial pattern of greening strongly suggests a large role for woody regrowth following land abandonment. Both land-use change and ecological dynamics are not well represented in current Earth system models, and may thus significantly improve ESM predictive ability. The importance of land-use change and ecological dynamics does not preclude effects of climate change; particularly drying in southern Europe and winter/ spring warming in northern Europe (European Environment Agency, 2017), N deposition (McCarthy, Oren, Finzi, \& Johnsen, 2006) or direct effects of elevated atmospheric $\mathrm{CO}_{2}$ on for example, community composition or the rate of woody canopy closure (Körner, 
2006; LaDeau \& Clark, 2001). Both climate change and $\mathrm{CO}_{2}$ may not only act directly at the physiological level to stimulate carbon assimilation and growth, but also construct novel ecosystems by affecting species ranges and competitive interactions within plant communities, which are both likely contributors to observed greening.

\section{ACKNOWLEDGEMENTS}

The authors acknowledge support from the $\mathrm{BACl}$ project funded under European Union's Horizon 2020 Research and Innovation Programme under grant agreement No. 640176. JCS considers this work a contribution to his Carlsberg Foundation Semper Ardens project MegaPast2Future (CF16-0005) and to his VILLUM Investigator project "Biodiversity Dynamics in a Changing World" funded by VILLUM FONDEN (grant 16549).

\section{CONFLICT OF INTEREST}

The authors are not aware of any conflict of interest.

\section{ORCID}

Robert Buitenwerf (iD http://orcid.org/0000-0003-3356-2301

\section{REFERENCES}

Aleman, J. C., \& Staver, A. C. (2018). Spatial patterns in the global distributions of savanna and forest. Global Ecology and Biogeography, 27, 792-803. https://doi.org/10.1111/geb.12739

Anav, A., Murray-Tortarolo, G., Friedlingstein, P., Sitch, S., Piao, S. L., \& Zhu, Z. C. (2013). Evaluation of land surface models in reproducing satellite Derived leaf area index over the high-latitude northern hemisphere. Part II: Earth system models. Remote Sensing, 5, 3637-3661. https://doi.org/10.3390/rs5083637

Bader, M. K. F., Leuzinger, S., Keel, S. G., Siegwolf, R. T. W., Hagedorn, F., Schleppi, P., \& Körner, C. (2013). Central European hardwood trees in a high- $\mathrm{CO}_{2}$ future: Synthesis of an 8-year forest canopy $\mathrm{CO}_{2}$ enrichment project. Journal of Ecology, 101, 1509-1519.

Bignal, E. M., \& Mccracken, D. I. (2000). The nature conservation value of European traditional farming systems. Environmental Reviews, 8, 149-171. https://doi.org/10.1139/a00-009

Bonan, G. B. (2016). Forests, climate, and public policy: A 500-year interdisciplinary odyssey. Annual Review of Ecology, Evolution, and Systematics, 47, 97-121. https://doi.org/10.1146/annurev-ecolsys-121415032359

Bond, W. J., Woodward, F. I., \& Midgley, G. F. (2005). The global distribution of ecosystems in a world without fire. New Phytologist, 165, 525-537. https://doi.org/10.1111/j.1469-8137.2004.01252.x

Buitenwerf, R., Rose, L., \& Higgins, S. I. (2015). Three decades of multi-dimensional change in global leaf phenology. Nature Climate Change, 5 , 364-368. https://doi.org/10.1038/nclimate2533

Castro, J., Zamora, R., Hódar, J. A., \& Gómez, J. M. (2005). Alleviation of summer drought boosts establishment success of Pinus sylvestris in a Mediterranean mountain: An experimental approach. Plant Ecology, 181, 191-202. https://doi.org/10.1007/s11258-005-6626-5

Churski, M., Bubnicki, J. W., Jedrzejewska, B., Kuijper, D. P., \& Cromsigt, J. P. (2017). Brown world forests: Increased ungulate browsing keeps temperate trees in recruitment bottlenecks in resource hotspots. New Phytologist, 214, 158-168. https://doi.org/10.1111/nph.14345

Ciais, P., Reichstein, M., Viovy, N., Granier, A., Ogée, J., Allard, V., .. Valentini, R. (2005). Europe-wide reduction in primary productivity caused by the heat and drought in 2003. Nature, 437, 529-533. https://doi.org/10.1038/nature03972

Cohen, J., Pulliainen, J., Menard, C. B., Johansen, B., Oksanen, L., Luojus, K., \& Ikonen, J. (2013). Effect of reindeer grazing on snowmelt, albedo and energy balance based on satellite data analyses. Remote Sensing of Environment, 135, 107-117. https://doi.org/10.1016/j.rse. 2013.03.029

Cramer, V. A., Hobbs, R. J., \& Standish, R. J. (2008). What's new about old fields? Land abandonment and ecosystem assembly. Trends in Ecology and Evolution, 23, 104-112. https://doi.org/10.1016/j.tree. 2007.10.005

De Jong, R., Verbesselt, J., Schaepman, M. E., \& Bruin, S. (2012). Trend changes in global greening and browning: Contribution of short-term trends to longer-term change. Global Change Biology, 18, 642-655. https://doi.org/10.1111/j.1365-2486.2011.02578.x

den Herder, M., Virtanen, R., \& Roininen, H. (2008). Reindeer herbivory reduces willow growth and grouse forage in a forest-tundra ecotone. Basic and Applied Ecology, 9, 324-331. https://doi.org/10.1016/ j.baae.2007.03.005

Estel, S., Kuemmerle, T., Alcantara, C., Levers, C., Prishchepov, A., \& Hostert, P. (2015). Mapping farmland abandonment and recultivation across Europe using MODIS NDVI time series. Remote Sensing of Environment, 163, 312-325. https://doi.org/10.1016/j.rse.2015.03. 028

European Commision (2017). Agri-environmental indicator - Livestock patterns. Retrieved from https://ec.europa.eu/eurostat/statisticsexplained/index.php/Agri-environmental_indicator_-_livestock_patte rns

European Environment Agency (2016a). Corine Land Cover (CLC) 2006, version 18.5.1. Retrieved from https://land.copernicus.eu/pan-eur opean/corine-land-cover/clc-2006

European Environment Agency (2016b). Natura 2000 data - The European network of protected sites. Retrieved from https://www.eea.eu ropa.eu/data-and-maps/data/natura-7

European Environment Agency (2017). Climate change, impacts and vulnerability in Europe 2016. European Environment Agency. Retrieved from https://www.eea.europa.eu/publications/climate-change-impac ts-and-vulnerability-2016

Fatichi, S., Leuzinger, S., \& Körner, C. (2014). Moving beyond photosynthesis: From carbon source to sink-driven vegetation modeling. New Phytologist, 201, 1086-1095. https://doi.org/10.1111/nph.12614

Forkel, M., Carvalhais, N., Verbesselt, J., Mahecha, M. D., Neigh, C. S. R., \& Reichstein, M. (2013). Trend change detection in NDVI time series: Effects of inter-annual variability and methodology. Remote Sensing, 5, 2113-2144. https://doi.org/10.3390/rs5052113

Freese, A., Benes, J., Bolz, R., Cizek, O., Dolek, M., Geyer, A., ... Stettmer, C. (2006). Habitat use of the endangered butterfly Euphydryas maturna and forestry in Central Europe. Animal Conservation, 9, 388397. https://doi.org/10.1111/j.1469-1795.2006.00045.x

Fridley, J. D. (2012). Extended leaf phenology and the autumn niche in deciduous forest invasions. Nature, 485, 359-362. https://doi.org/10. 1038/nature11056

Fuchs, R., Herold, M., Verburg, P. H., Clevers, J. G., \& Eberle, J. (2015). Gross changes in reconstructions of historic land cover/use for Europe between 1900 and 2010. Global Change Biology, 21, 299-313. https://doi.org/10.1111/gcb.12714

Garonna, I., de Jong, R., de Wit, A. J., Mucher, C. A., Schmid, B., \& Schaepman, M. E. (2014). Strong contribution of autumn phenology to changes in satellite-derived growing season length estimates across Europe (1982-2011). Global Change Biology, 20, 3457-3470. https://doi.org/10.1111/gcb.12625 
Gellrich, M., Baur, P., Koch, B., \& Zimmermann, N. E. (2007). Agricultural land abandonment and natural forest re-growth in the Swiss mountains: A spatially explicit economic analysis. Agriculture Ecosystems and Environment, 118, 93-108. https://doi.org/10.1016/j.agee.2006. 05.001

Gill, R. M. A., \& Morgan, G. (2010). The effects of varying deer density on natural regeneration in woodlands in lowland Britain. Forestry, 83, 53-63. https://doi.org/10.1093/forestry/cpp031

Guilherme, J. L., \& Pereira, H. M. (2013). Adaptation of bird communities to farmland abandonment in a mountain landscape. PLoS One, 8, e73619.

Hagen, S. B., Jepsen, J. U., Ims, R. A., \& Yoccoz, N. G. (2007). Shifting altitudinal distribution of outbreak zones of winter moth Operophtera brumata in sub-arctic birch forest: A response to recent climate warming? Ecography, 30, 299-307.

Hernández, L., Sánchez de Dios, R., Montes, F., Sainz-Ollero, H., \& Canellas, I. (2017). Exploring range shifts of contrasting tree species across a bioclimatic transition zone. European Journal of Forest Research, 136, 481-492. https://doi.org/10.1007/s10342-017-1047-2

Hickler, T., Vohland, K., Feehan, J., Miller, P. A., Smith, B., Costa, L., ... Sykes, M. T. (2012). Projecting the future distribution of European potential natural vegetation zones with a generalized, tree speciesbased dynamic vegetation model. Global Ecology and Biogeography, 21, 50-63. https://doi.org/10.1111/j.1466-8238.2010.00613.x

Hijmans, R. J. (2018). raster: Geographic data analysis and modeling. Retrieved from https://CRAN.R-project.org/package=raster

Jepsen, J. U., Hagen, S. B., Hogda, K. A., Ims, R. A., Karlsen, S. R., Tommervik, H., \& Yoccoz, N. G. (2009). Monitoring the spatio-temporal dynamics of geometrid moth outbreaks in birch forest using MODISNDVI data. Remote Sensing of Environment, 113, 1939-1947. https://doi.org/10.1016/j.rse.2009.05.006

Jung, M., Reichstein, M., Schwalm, C. R., Huntingford, C., Sitch, S., Ahlström, A., ... Zeng, N. (2017). Compensatory water effects link yearly global land $\mathrm{CO}_{2}$ sink changes to temperature. Nature, 541, 516-520. https://doi.org/10.1038/nature20780

Körner, C. (2006). Plant $\mathrm{CO}_{2}$ responses: An issue of definition, time and resource supply. New Phytologist, 172, 393-411.

Körner, C., Basler, D., Hoch, G., Kollas, C., Lenz, A., Randin, C. F., ... Zimmermann, N. E. (2016). Where, why and how? Explaining the lowtemperature range limits of temperate tree species. Journal of Ecology, 104, 1076-1088. https://doi.org/10.1111/1365-2745.12574

Kremer, F., Van Der Stegen, J., Gomez-Zamalloa, M. G., \& Szedlak, T. (2015). Natura 2000 and forests Part I-II. European Commission. Retrieved from https://ec.europa.eu/environment/nature/natura 2000/management/docs/Final\%20Guide\%20N2000\%20\%20Forests\% 20Part\%20I-II-Annexes.pdf

Kuemmerle, T., Levers, C., Erb, K., Estel, S., Jepsen, M. R., Müller, D., ... Reenberg, A. (2016). Hotspots of land use change in Europe. Environmental Research Letters, 11, 064020. https://doi.org/10.1088/17489326/11/6/064020

Ladeau, S. L., \& Clark, J. S. (2001). Rising $\mathrm{CO}_{2}$ levels and the fecundity of forest trees. Science, 292, 95-98. https://doi.org/10.1126/science. 1057547

Lassauce, A., Paillet, Y., Jactel, H., \& Bouget, C. (2011). Deadwood as a surrogate for forest biodiversity: Meta-analysis of correlations between deadwood volume and species richness of saproxylic organisms. Ecological Indicators, 11, 1027-1039. https://doi.org/10.1016/ j.ecolind.2011.02.004

Lloret, F., Siscart, D., \& Dalmases, C. (2004). Canopy recovery after drought dieback in holm-oak Mediterranean forests of Catalonia (NE Spain). Global Change Biology, 10, 2092-2099. https://doi.org/10. 1111/j.1365-2486.2004.00870.x

Lomba, A., Alves, P., Jongman, R. H., \& Mccracken, D. I. (2015). Reconciling nature conservation and traditional farming practices: A spatially explicit framework to assess the extent of High Nature Value farmlands in the European countryside. Ecology and Evolution, 5, 1031-1044. https://doi.org/10.1002/ece3.1415

Macdonald, D., Crabtree, J. R., Wiesinger, G., Dax, T., Stamou, N., Fleury, P., ... Gibon, A. (2000). Agricultural abandonment in mountain areas of Europe: Environmental consequences and policy response. Journal of Environmental Management, 59, 47-69. https://doi.org/10.1006/je ma.1999.0335

Mao, J. F., Ribes, A., Yan, B. Y., Shi, X., Thornton, P. E., Séférian, R., ... Lian, X. (2016). Human-induced greening of the northern extratropical land surface. Nature Climate Change, 6, 959-963. https://doi.org/ 10.1038/nclimate3056

Marchetto, A. (2015). rkt: Mann-Kendall test, seasonal and regional Kendall tests. Retrieved from https://CRAN.R-project.org/package=rkt

Mccarthy, H. R., Oren, R., Finzi, A. C., \& Johnsen, K. H. (2006). Canopy leaf area constrains $\left[\mathrm{CO}_{2}\right]$-induced enhancement of productivity and partitioning among aboveground carbon pools. Proceedings of the National Academy of Sciences of the United States of America, 103, 19356-19361. https://doi.org/10.1073/pnas.0609448103

Menzel, A., Sparks, T. H., Estrella, N., Koch, E., Aasa, A., Ahas, R., ... Zust, A. (2006). European phenological response to climate change matches the warming pattern. Global Change Biology, 12, 1969-1976. https://doi.org/10.1111/j.1365-2486.2006.01193.x

Mora, O., Banos, V., Regolini, M., \& Carnus, J. M. (2014). Using scenarios for forest adaptation to climate change: A foresight study of the Landes de Gascogne Forest 2050. Annals of Forest Science, 71, 313-324. https://doi.org/10.1007/s13595-013-0336-2

Murray-Tortarolo, G., Anav, A., Friedlingstein, P., Sitch, S., Piao, S., Zhu, Z., ... Zeng, N. (2013). Evaluation of land surface models in reproducing satellite-derived LAI over the high-latitude Northern Hemisphere. Part I: Uncoupled DGVMs. Remote Sensing, 5, 4819-4838. https://d oi.org/10.3390/rs5104819

Musavi, T., Migliavacca, M., Reichstein, M., Kattge, J., Wirth, C., Black, T. A., ... Mahecha, M. D. (2017). Stand age and species richness dampen interannual variation of ecosystem-level photosynthetic capacity. Nature Ecology and Evolution, 1, 48. https://doi.org/10.1038/s41559016-0048

Myneni, R., Knyazikhin, Y., \& Park, T. (2015). MCD15A2H MODIS/Terra+Aqua Leaf Area Index/FPAR 8-day L4 Global 500m SIN Grid V006. NASA EOSDIS Land Processes DAAC. https://doi.org/10.5067/ MODIS/MCD15A2H.006.

Navarro, L. M., \& Pereira, H. M. (2012). Rewilding abandoned landscapes in Europe. Ecosystems, 15, 900-912. https://doi.org/10.1007/ s10021-012-9558-7

Nemani, R. R., Keeling, C. D., Hashimoto, H., Jolly, W. M., Piper, S. C., Tucker, C. J., ... Running, S. W. (2003). Climate-driven increases in global terrestrial net primary production from 1982 to 1999 . Science, 300, 1560-1563. https://doi.org/10.1126/science.1082750

Ódor, P., Heilmann-Clausen, J., Christensen, M., Aude, E., vanDort, K. W., Piltaver, A., ... Grebenc, T. (2006). Diversity of dead wood inhabiting fungi and bryophytes in semi-natural beech forests in Europe. Biological Conservation, 131, 58-71. https://doi.org/10.1016/j.biocon.2006. 02.004

Olmeda, C., Keenleyside, C., Tucker, G., \& Underwood, E. (2014). Farming for Natura 2000. European Commission. European Commission. Retrieved from https://ec.europa.eu/environment/nature/natura 2000/management/docs/FARMING\%20FOR\%20NATURA\%202000final\%20guidance.pdf

Osborne, C. P., \& Beerling, D. J. (2006). Nature's green revolution: The remarkable evolutionary rise of $\mathrm{C}_{4}$ plants. Philosophical Transactions of the Royal Society London B Biological Sciences, 361, 173-194. https://doi.org/10.1098/rstb.2005.1737

Plieninger, T., Draux, H., Fagerholm, N., Bieling, C., Bürgi, M., Kizos, T., ... Verburg, P. H. (2016). The driving forces of landscape change in Europe: A systematic review of the evidence. Land Use Policy, 57, 204 214. https://doi.org/10.1016/j.landusepol.2016.04.040 
Pretzsch, H., Biber, P., Schutze, G., Uhl, E., \& Rotzer, T. (2014). Forest stand growth dynamics in Central Europe have accelerated since 1870. Nature Communication, 5, 4967. https://doi.org/10.1038/nc omms5967

Putman, R., Langbein, J., Green, P., \& Watson, P. (2011). Identifying threshold densities for wild deer in the UK above which negative impacts may occur. Mammal Review, 41, 175-196. https://doi.org/10. 1111/j.1365-2907.2010.00173.x

Queiroz, C., Beilin, R., Folke, C., \& Lindborg, R. (2014). Farmland abandonment: Threat or opportunity for biodiversity conservation? A global review. Frontiers in Ecology and the Environment, 12, 288-296. https://doi.org/10.1890/120348

, R Core Team (2018). R: A language and environment for statistical computing. Vienna, Austria: R Foundation for Statistical Computing. https://www.R-project.org/

Regos, A., Dominguez, J., Gil-Tena, A., Brotons, L., Ninyerola, M., \& Pons, X. (2016). Rural abandoned landscapes and bird assemblages: Winners and losers in the rewilding of a marginal mountain area (NW Spain). Regional Environmental Change, 16, 199-211. https://doi.org/ 10.1007/s10113-014-0740-7

Reich, P. B., Walters, M. B., \& Ellsworth, D. S. (1997). From tropics to tundra: Global convergence in plant functioning. Proceedings of the National Academy of Sciences of the United States of America, 94, 13730-13734. https://doi.org/10.1073/pnas.94.25.13730

Sandom, C. J., Ejrnaes, R., Hansen, M. D., \& Svenning, J. C. (2014). High herbivore density associated with vegetation diversity in interglacial ecosystems. Proceedings of the National Academy of Sciences of the United States of America, 111, 4162-4167. https://doi.org/10.1073/ pnas.1311014111

Skaloš, J., Novotný, M., Woitsch, J., Zacharová, J., Berchová, K., Svoboda, M., ... Keken, Z. (2015). What are the transitions of woodlands at the landscape level? Change trajectories of forest, non-forest and reclamation woody vegetation elements in a mining landscape in North-western Czech Republic. Applied Geography, 58, 206-216. https://doi.org/10.1016/j.apgeog.2015.02.003

Smit, C., Ruifrok, J. L., Van Klink, R., \& Olff, H. (2015). Rewilding with large herbivores: The importance of grazing refuges for sapling establishment and wood-pasture formation. Biological Conservation, 182, 134-142. https://doi.org/10.1016/j.biocon.2014.11.047

Steffen, W., Broadgate, W., Deutsch, L., Gaffney, O., \& Ludwig, C. (2015). The trajectory of the Anthropocene: The great acceleration. The Anthropocene Review, 2, 81-98. https://doi.org/10.1177/ 2053019614564785

Svenning, J. C., Pedersen, P. B., Donlan, C. J., Ejrnæs, R., Faurby, S., .. Galetti, M. (2016). Science for a wilder Anthropocene: Synthesis and future directions for trophic rewilding research. Proceedings of the National Academy of Sciences of the United States of America, 113, 898-906. https://doi.org/10.1073/pnas.1502556112

Svenning, J. C., \& Sandel, B. (2013). Disequilibrium vegetation dynamics under future climate change. American Journal of Botany, 100, 12661286. https://doi.org/10.3732/ajb.1200469

Svenning, J. C., \& Skov, F. (2004). Limited filling of the potential range in European tree species. Ecology Letters, 7, 565-573. https://doi.org/ 10.1111/j.1461-0248.2004.00614.x

Thiele, J., Kollmann, J., \& Andersen, U. R. (2009). Ecological and socioeconomic correlates of plant invasions in Denmark: The utility of environmental assessment data. Ambio, 38, 89-94. https://doi.org/ 10.1579/0044-7447-38.2.89

Timmermann, A., Damgaard, C., Strandberg, M. T., \& Svenning, J. C. (2015). Pervasive early 21st-century vegetation changes across Danish semi-natural ecosystems: More losers than winners and a shift towards competitive, tall-growing species. Journal of Applied Ecology, 52, 21-30. https://doi.org/10.1111/1365-2664.12374

Trabucco, A., \& Zomer, R. J. (2010). Global soil water balance geospatial database. CGIAR Consortium for Spatial Information. Published online, retrieved from the CGIAR-CSI GeoPortal at https://www.cgia r-csi.org

Van Swaay, C., Warren, M., \& Loïs, G. (2006). Biotope use and trends of European butterflies. Journal of Insect Conservation, 10, 189-209. https://doi.org/10.1007/s10841-006-6293-4

Van Wieren, S. E. (1995). The potential role of large herbivores in nature conservation and extensive land use in Europe. Biological Journal of the Linnean Society, 56, 11-23. https://doi.org/10.1111/j.1095-8312. 1995.tb01114.x

Verbesselt, J., Hyndman, R., Newnham, G., \& Culvenor, D. (2010) Detecting trend and seasonal changes in satellite image time series. Remote Sensing of Environment, 114, 106-115. https://doi.org/10. 1016/j.rse.2009.08.014

Verbesselt, J., Umlauf, N., Hirota, M., Holmgren, M., VanNes, E. H., Herold, M., ... Scheffer, M. (2016). Remotely sensed resilience of tropical forests. Nature Climate Change, 6, 1028-1031. https://doi.org/10. 1038/nclimate3108

Walther, G. R., Gritti, E. S., Berger, S., Hickler, T., Tang, Z. Y., \& Sykes, M. T. (2007). Palms tracking climate change. Global Ecology and Biogeography, 16, 801-809. https://doi.org/10.1111/j.1466-8238.2007.00328.x

Woodward, F. I. (1987). Stomatal numbers are sensitive to increases in $\mathrm{CO}_{2}$ from pre-industrial levels. Nature, 327, 617-618. https://doi.org/ 10.1038/327617a0

Young, A. B., Cairns, D. M., Lafon, C. W., \& Moen, J. (2014). Geometrid moth outbreaks and their climatic relations in northern Sweden. Arctic Antarctic and Alpine Research, 46, 659-668. https://doi.org/10. 1657/1938-4246-46.3.659

Zhu, Z. C., Piao, S. L., Myneni, R. B., Huang, M., Zeng, Z., Canadell, J. G., .. Zeng, N. (2016). Greening of the Earth and its drivers. Nature Climate Change, 6, 791-795. https://doi.org/10.1038/nclimate3004 